NBER WORKING PAPER SERIES

\title{
MONEY IN MOTION: \\ DYNAMIC PORTFOLIO CHOICE IN RETIREMENT
}

\author{
Wolfram J. Horneff \\ Raimond H. Maurer \\ Olivia S. Mitchell \\ Michael Z. Stamos \\ Working Paper 12942 \\ http://www.nber.org/papers/w12942
NATIONAL BUREAU OF ECONOMIC RESEARCH
1050 Massachusetts Avenue
Cambridge, MA 02138
February 2007

This research was conducted with support from the US Social Security Administration via the Michigan Retirement Research Center at the University of Michigan. Additional research support was provided by the German Investment and Asset Management Association (BVI), the German Research Foundation (DFG), the Fritz-Thyssen Foundation, the Observatoire de l'Epargne Europeenne (OEE), and the Pension Research Council (PRC) at The Wharton School of the University of Pennsylvania. We are grateful for useful comments from John Ameriks, Jeffrey Brown, and Christian Gollier.The views expressed herein are those of the authors and do not necessarily reflect the views of the National Bureau of Economic Research or the other institutions with which the authors are affiliated. This is part of the NBER Program on the Economics of Aging.

(C) 2007 by Wolfram J. Horneff, Raimond H. Maurer, Olivia S. Mitchell, and Michael Z. Stamos. All rights reserved. Short sections of text, not to exceed two paragraphs, may be quoted without explicit permission provided that full credit, including $\odot$ notice, is given to the source. 
Money in Motion: Dynamic Portfolio Choice in Retirement

Wolfram J. Horneff, Raimond H. Maurer, Olivia S. Mitchell, and Michael Z. Stamos

NBER Working Paper No. 12942

February 2007

JEL No. D14,G11,G22,G23,H55,J26

\begin{tabular}{|c|c|}
\hline \multicolumn{2}{|c|}{ ABSTRACT } \\
\hline \multicolumn{2}{|c|}{$\begin{array}{l}\text { Retirees confront the difficult problem of how to manage their money in retirement so as to not outlive } \\
\text { their funds while continuing to invest in capital markets. We posit a dynamic utility maximizer wh } \\
\text { makes both asset location and allocation decisions when managing her retirement financial weal } \\
\text { and annuities, and we prove that she can benefit from both the equity premium and longevity insuran } \\
\text { in her retirement portfolio. Even without bequests, she will not fully annuitize; rather, her optim } \\
\text { stock allocation amounts initially to more than half of her financial wealth and declines with age. Welfa } \\
\text { gains from this strategy can amount to } 40 \text { percent of financial wealth (depending on risk paramete } \\
\text { and other resources). In practice, it turns out that many retirees will do almost as well by purchasir } \\
\text { a variable annuity invested } 60 / 40 \text { in stocks/bonds. }\end{array}$} \\
\hline Wolfram J. Horneff & Olivia S. Mitchell \\
\hline Finance Department, Goethe University & Department of Insurance \& Risk Management \\
\hline Kettenhofweg 139 (Uni-PF. 58) & University of Pennsylvania, Wharton School \\
\hline Frankfurt am Main & 3620 Locust Walk, St 3000 SH-DH \\
\hline Germany & Philadelphia, PA 19104-6302 \\
\hline horneff@finance.uni-frankfurt.de & and NBER \\
\hline & mitchelo@wharton.upenn.edu \\
\hline \multicolumn{2}{|l|}{ Raimond H. Maurer } \\
\hline Finance Department, Goethe University & Michael Z. Stamos \\
\hline Kettenhofweg 139 (Uni-PF. 58) & Finance Department, Goethe University \\
\hline Frankfurt am Main, Germany & Kettenhofweg 139 (Uni-PF. 58) \\
\hline rmaurer@wiwi.uni-frankfurt.de & Frankfurt am Main \\
\hline & $\begin{array}{l}\text { Germany } \\
\text { stamos@finance.uni-frankfurt.de }\end{array}$ \\
\hline
\end{tabular}




\section{Money in Motion: Dynamic Portfolio Choice in Retirement}

As Baby Boomers move into their 60s, increasing attention is being devoted to the prospect of $\$ 15$ trillion in assets that retirees will be required to manage over what promises to be a very long period (McKinsey, 2006). A financial product that offers some promise in this regard is the lifetime payout annuity, which represents a promise by an insurer to pay benefits over the retiree’s remaining lifetime, no matter how long she lives. Lifetime annuities can augment retirement security, as they allow the retiree to protect against outliving her assets while enhancing expected returns through the "mortality credit." ${ }^{\text {"1 }}$ Most annuities currently sold in the United States are of the variable type where purchasers can invest in capital market assets, yet these have been little studied by researchers. Instead, the bulk of previous studies have focused on “fixed payout annuities,” or annuities that pay a flat benefit. $^{2}$ Also, little prior analysis has explored optimal dynamic portfolio choices in retirement involving variable payout annuities. ${ }^{3}$

Our paper fills this research gap by exploring how variable payout annuities can help a retiree access stock markets during the decumulation phase of her lifecycle, while still permitting her to take advantage of the additional expected returns and hedge mortality risk using annuity products. Specifically, we derive an optimal endogenous gradual annuitization strategy and asset allocation pattern for a risk-averse retiree facing stochastic lifetime and endowed with pension

\footnotetext{
${ }^{1}$ The mortality credit refers to the extra income received by surviving annuity buyers resulting from sharing in the committed assets of decedents; c.f. Brown et al. (2001), Feldstein and Ranguelova (2001), and Mitchell et al. (1999). ${ }^{2}$ For instance, Dus, Maurer, and Mitchell (2005); Gerrard, Haberman, and Vigna (2004); Horneff, Maurer, Mitchell, and Dus (2006); Kaplan (2006)' Kapur and Orszag (1999); Kingston and Thorp (2005; Milevsky (1998); Milevsky and Young (2002); Milevsky, Moore, and Young (2006); Mitchell, Poterba, Warshawsky, and Brown (1999); and Stabile (2003).

${ }^{3}$ Several papers have explored variable annuities but adopt restrictive annuitization and asset allocation patterns; c.f. Blake, Cairns and Dowd (2003); Browne, Milevsky and Salisbury (2001); Brown, Mitchell and Poterba (2001); Charupat and Milevsky (2002); Feldstein and Ranguelova (2001); Koijen, Nijman, and Werker (2006); Milevsky (2002); and Milevsky and Young (2006a and b).
} 
income. She must make both an asset location choice, regarding how much of her funds to hold in liquid financial wealth versus variable payout annuities, and also an asset allocation decision, where she elects how much of her portfolio to hold in risky stocks versus riskless bonds. Adding a variable annuity to the retirement portfolio can be preferred to direct investments, since the annuity pays superior expected returns due to the fact that surviving annuitants receive the distributed funds of those who die prematurely. On the other hand, once the retiree buys an annuity, the annuity principal can no longer be recovered.

In contrast to previous studies, we show that the retiree will not fully annuitize immediately on retirement, even if she lacks a bequest motive. Rather, she will initially, partially annuitize and hold 50-100 percent of her remaining financial assets in stocks. As she ages, she will gradually buy more annuities and optimally replace stocks with bonds in the portfolio. Next, we show how these choices respond to capital market shocks: in particular, the retiree's stock fraction varies countercyclically, a finding that diverges from other studies which favor a procyclical buy-and-hold strategy. Our welfare analysis indicates that restricting retirees to simple phased withdrawal plans is distinctly suboptimal, such that they would have to be given up to 40 percent more initial wealth, to leave them as well off as with variable payout annuities.

The fact that variable annuities can substantially enhance retirement security is particularly relevant to policymakers, including those in the US who seek to implement funded Personal Retirement Accounts (PRAs) in a revamped Social Security system. For instance Feldstein and Ranguelova (2001) note that retirees who purchase immediate annuities invested 60/40 in stocks/bonds could be anticipated to fare better than under the current Social Security system rules. Our analysis takes this a step further by evaluating the potential for welfare gains 
from endogenous optimal gradual annuitization and dynamic asset management over the entire retirement period.

In what follows, we first offer a brief literature overview and discussion of the mechanics of variable payout annuities. Next we derive and discuss the optimal annuitization and asset allocation strategy for a base case. ${ }^{4}$ Subsequently, we examine the welfare gains from expanding the asset space using variable annuities. A final section concludes.

\section{Prior Studies}

Yaari’s (1965) important study on how to protect against outliving one’s money suggested that a rational retiree lacking a bequest motive would annuitize all her assets. In his framework, the investor is exposed only to mortality risk and all annuities are fairly priced from an actuarial standpoint (other sources of risk due to interest rates, stocks, and inflation are omitted). In an important recent extension of that work, Davidoff, Brown, and Diamond (2005) conclude that a retiree will still fully annuitize financial wealth in the presence of a complete market if there is no bequest motive, when the net return on the annuity is greater than that of the reference asset. Partial annuitization could be optimal if the assumption about complete markets is relaxed, or if the investor has a bequest motive.

The complete markets assumption requires that there will be term life annuities available for purchase that pay out at each future date. But since real-world annuity providers tend to offer fixed payouts, several researchers have formulated more realistic dynamic portfolio choice models that incorporate mainly fixed payout annuities. Initially, this literature assumed a restricted annuitization strategy, where all wealth must be either fully annuitized immediately on

\footnotetext{
${ }^{4}$ There is no analytic solution for this problem in either discrete or continuous time, so we employ numerical dynamic optimization techniques in what follows.
} 
retirement or later; more recent studies have endogenized the annuitization decision, allowing retirees to gradually annuitize at any age and repeatedly. ${ }^{5}$

Less well studied is the proposition that annuity purchasers may do better if they turn to variable payout annuities, instead of merely fixed payout products. Some research compares variable payout annuities to other asset classes on an "either-or" basis: for instance Blake, Cairns, and Dowd (2003) show that equity-linked variable annuities should appeal to many retirees (across a range of risk preferences), compared to either a phased withdrawal plan or a fixed payout annuity. Brown, Mitchell, and Poterba (2001) show that variable payout annuities can hedge inflation risk better than equity-linked annuities, by investing the underlying funds in inflation-indexed bonds. At the same time, though, they find that pure equity-linked annuities can generate greater utility than real annuities for a broad range of risk aversion parameters. Using Monte Carlo simulation, Milevsky (2002) compares risk/return characteristics of variable payout annuity payout streams with fixed and escalating annuities, and he argues that variable payout annuities may hedge inflation better than escalating annuities.

While these studies analyze portfolio choice problems which include variable payout annuities, they are still restrictive in important ways. For instance, with respect to the asset location decision, they all require that financial wealth must be fully annuitized, yet this is unlikely in practice. Regarding the annuitization timing decision, most prior studies require that annuities be bought immediately on retirement; for instance Milevsky and Young (2002, 2006b) endogenize the timing of the annuity purchase but they do not allow for partial and gradual annuitization. Also, few studies have endogenized the optimal asset allocation of the annuity portfolio, and the ones that do, restrict the retiree to a so-called "money mix" plan, which is a

\footnotetext{
${ }^{5}$ For studies analyzing portfolio choice problems with gradual annuitization we refer the interested reader to Milevsky and Young (2003), and Horneff, Maurer, and Stamos (2006a, 2006b).
} 
one-time irreversible buy and hold portfolio of fixed and fully equity-linked annuities. ${ }^{6}$

In what follows, we extend prior literature in several ways. First, we endogenize the retiree’s annuitization (or asset location) decision, permitting her to dynamically and gradually buy variable payout annuities by drawing down her financial wealth during retirement. Accordingly, we do not force full annuitization, but rather we allow both partial and gradual annuitization and model variable payout annuities on an equal footing with stocks and bonds. Second, we optimize the asset allocation decision asset endogenously and dynamically, in both the non-annuitized financial portfolio and the variable payout annuity. Consequently, the retiree may rebalance her asset mix within the variable payout annuity optimally according to state variables, whereas prior work optimized only the initial buy and hold mix between equity-linked and constant annuities. ${ }^{7}$ Third, we contribute to the literature by incorporating a bequest motive explicitly, to characterize the tradeoff between the annuity mortality credit and the bequest potential of non-annuitized financial wealth. Finally, we examine the sensitivity of key decisions to the retiree's risk aversion and starting levels of wealth.

\section{The Mechanics of Variable Payout Annuities}

Our work focuses on variable payout annuities which are financial contracts between a retiree and an insurer. In return for the initial annuity premium $P R_{0}$, the annuity buyer receives a pre-specified number of fund units $n_{t}$ in each period $t \in\{1,2, \ldots, \tau\}$. Here $T$ is assumed to be the retiree's maximum possible survival age, and $\tau \in\{1, \ldots, T\}$ is her stochastic date of death,

\footnotetext{
${ }^{6}$ See Charupat and Milevsky (2002), Koijen, Nijman, and Werker (2006), Browne, Milevsky, and Salisbury (2003), and Milevsky and Young (2006a). None of these endogenizes the asset location and allocation decisions dynamically, as we do below. Browne et al. (2003) assess welfare losses from a stylized case where only fixed/equity linked annuities can be exchanged for each other.

${ }^{7}$ By optimizing the portfolio within the underlying annuity fund we bypass the stylized assumption of Browne et al. (2003) in which only fixed and equity-linked annuities are exchanged.
} 
distributed according to ${ }_{x+t} p_{x}^{a}$ which refers to the cumulative survival probability that an individual of age $x$ survives to age $x+t$. In this setup, the payment $P O_{t}$ paid to the annuitant in year $t$, conditional on her being alive, is $P O_{t}^{a}=Z_{t}^{a} n_{t}$, where $Z_{t}^{a}$ is the price of one annuity fund unit at time $t$ which evolves according to $Z_{t+1}^{a}=Z_{t}^{a} R_{t+1}^{a}$, and $R_{t+1}^{a}$ is the gross return on investment of the annuity fund in period $t+1$. The gross return can be stochastic when the underlying funds inside the annuity wrapper are held in risky assets. Thus, while the number of fund units received is deterministic, the payout in monetary terms is stochastic when the annuity is invested in risky assets. If the insurance pool is sufficiently large, the premium for the payout process (1) can be calculated according to the actuarial principle of equivalence:

$$
P R_{0}=N_{0} Z_{0}
$$

where $N_{0}=\sum_{t=1}^{T}{ }_{x+t} p_{x}^{a} n_{t}$ is the number of fund units needed to back the expected future payout stream $n_{t}$, for $t \in\{1,2, \ldots, \tau\}$. Then the premium paid for a variable payout annuity only depends on the current price of the annuity fund, the fund unit stream, and survival probabilities.

$$
\text { Simple algebra yields } P R_{0}=\sum_{t=1}^{T} \frac{{ }_{x+t} p_{x}^{a} P O_{t}^{a}}{R(0, t)} \text {, where } R(0, t)=Z_{t}^{a} / Z_{0}^{a} \text { is the cumulative }
$$

return of the annuity fund. In other words, the premium can be interpreted as the sum of discounted and survival probability-weighted payouts. Rearranging the premium function yields $P R_{0}=\sum_{t=1}^{T} \frac{P O_{t}^{a}}{\left({ }_{x+t} p_{x}^{a}\right)^{-1} R(0, t)} \cdot{ }^{8}$ This expression shows that the discount rate is higher than the pure

\footnotetext{
${ }^{8}$ If the annuity funds were invested only in riskless bonds, we would obtain the classical result for constant payout annuities: $P R_{0}=\sum_{t=1}^{T} \frac{{ }_{x+t} p_{x}^{a} P O_{t}^{a}}{R_{f}^{t}}$, where $R_{f}$ is the riskless growth rate.
} 
market return since $\left({ }_{x+t} p_{x}^{a}\right)^{-1}>1$; this mortality credit is attributable to the assets shared among surviving members of the insurance pool when members die. Accordingly, variable payout annuities cannot be replicated through direct investments in stocks and bonds.

The Assumed Interest Rate (AIR) and Payouts. Pricing variable payout annuities does not require any assumption about the functional form in general, insofar as the process for the fund units $n_{t}$ is concerned. But in practice, it is convenient to introduce a functional form for $n_{t}$ which relies on the Assumed Interest Rate (AIR), a term conventionally found in insurance pricing. It is also useful to derive how the $A I R$ influences the distribution of payouts over time. ${ }^{9}$

In insurance terminology, the assumed interest rate refers to the "shrinkage rate" of the number of fund units over time: $1+A I R=\left(\frac{n_{t+1}}{n_{t}}\right)^{-1}$. Then the recursive evolution of payouts is given by:

$$
P O_{t+1}=P O_{t} \frac{R_{t+1}^{a}}{1+A I R}
$$

It is natural to refer the $A I R$ as the "assumed interest rate” because the conditional expected payout growth is $E_{t}\left[\frac{P O_{t+1}}{P O_{t}}\right]=\frac{E_{t}\left[R_{t+1}^{a}\right]}{1+A I R}$. To produce a payout stream constant in expectation, the $A I R$ must be set exactly equal to the expected return on the assets of the annuity fund $E\left[R_{t+1}^{a}\right]-1$. When this is the case, the reduction in the number of fund units due to payouts exactly offsets their expected price increase due to investment return. Having a fixed AIR implies that the number of fund units evolves exponentially (increasing or decreasing) according

\footnotetext{
${ }^{9}$ A 4 percent AIR is common in the US industry (c.f. the Vanguard and TIAA-CREF variable payout annuity websites); the US National Association of Insurance Commissioners requires that the AIR not exceed a nominal 5 percent.
} 
to the rule $n_{t}=n_{1}\left(\frac{1}{(1+A I R)}\right)^{t-1}$. The premium $P R$ is then:

$$
P R_{0}=Z_{0} n_{1} \sum_{t=1}^{T} \frac{{ }_{x+t} p_{x}^{a}}{(1+A I R)^{t-1}}
$$

where $\sum_{t=1}^{T} \frac{{ }_{x+t} p_{x}^{a}}{(1+A I R)^{t-1}}$ is similar to the usual fixed annuity factor, but the riskless discount factor is now replaced by the $A I R$ in the case of the variable payout annuity.

Following the standard approach, the probability distribution for annuity payouts over time may be specified in assuming that prices of the annuity fund units evolve according to a multiplicative random walk with log-normal returns; in other words, $Z_{t}^{a}=Z_{t-1}^{a} R_{t+1}^{a}=Z_{t-1}^{a} e^{\mu^{a}+\sigma^{a} \varepsilon_{t}}$, with $Z_{0}^{a}=1$, where $\mu^{a}$ is the annuity fund's mean log-return, $\sigma^{a}$ is the standard deviation of the fund's $\log$-returns, and $\varepsilon_{t}$ is an i.i.d. standard normal distributed shock. These assumptions allow us to derive the probability distribution for annuity payouts over time. Specifically, from (2), the payout at $t$ is equal to $P O_{t}=\frac{n_{1}}{(1+A I R)^{t-1}} \prod_{s=1}^{t} R_{s}^{a}$. Hence, $P O_{t}$ is log-normally distributed with the mean and standard deviation:

$$
E\left[P O_{t}\right]=\frac{n_{1}}{(1+A I R)^{t-1}} e^{\mu^{a} t+\frac{1}{2}\left(\sigma^{a}\right)^{2} t} \text {, and } S T D\left[P O_{t}\right]=E\left[P O_{t}\right] \sqrt{e^{\left(\sigma^{a}\right)^{2} t}-1}
$$

The $\alpha$-percentile of the payout distribution in $t$ is then:

$$
P_{\alpha}\left(P O_{t}\right)=\frac{n_{1}}{(1+A I R)^{t-1}} e^{\mu^{a} t+N^{-1}(\alpha) \sigma^{a} \sqrt{t}}
$$

where $N^{-1}(\alpha)$ is the inverse of the normal distribution function.

To illustrate how variable annuity payments can vary given alternative asset allocations, we refer to Figure 1. Here Panel $(a)$ traces the $10^{\text {th }} / 90^{\text {th }}$ percentiles of payment outcomes for a 
$\$ 100,000$ immediate variable annuity, given three alternative stock allocations of 0,60 , and 100 percent, respectively. We assume that the expected real portfolio return with 100 (60) percent stocks is 6 (4.4) percent with a standard deviation of 18 (10.8) percent; ${ }^{10}$ the $A I R$ is 4 percent and the riskless rate 2 percent, respectively. ${ }^{11}$ (The variable annuity with 0 percent stocks and the $A I R$ set to 4 percent is equivalent to a riskless annuity with shrinking payouts.) The annuity stream can be seen to fall over time, because the AIR exceeds the return of the underlying portfolio. The two equity-linked annuity streams have a distribution skewed toward higher benefits over time, because setting the $A I R$ low compared to the expected annuity fund returns produces low payments initially, with higher benefits later on.

Figure 1 here

Panel (b) of Figure 1 illustrates how annuity payments would vary over time under alternative $A I R$ s of 2, 4, and 6 percent, assuming that the annuity fund is invested 60 percent in equities. It is clear that the higher the $A I R$, the larger is the initial payment and the lower is the later payout. For example, after age 75, the variable annuity payment using the lowest $A I R$ exceeds the benefit paid using the highest $A I R$. Accordingly, the retiree seeking high payouts early in the retirement period would select an annuity with an AIR higher than the expected fund return, and vice versa. It is also interesting that selecting a low $A I R$ results in a much higher dispersion of payments; nevertheless, this dispersion is reflected mainly in the upside potential

\footnotetext{
${ }^{10}$ The portfolio growth rate is log-normal with $E\left[R^{a}\right]=\pi E[R]+(1-\pi) R_{f}$ and $S T D\left[R^{a}\right]=\pi S T D[R]$. From the log-normality assumptions follows that $\mu^{a}=\ln \left(E\left[R^{a}\right]\right)-0.5\left(\sigma^{a}\right)^{2}$ and $\sigma^{a}=\sqrt{\ln \left(1+S T D\left[R^{a}\right]^{2} / E\left[R^{a}\right]^{2}\right)}$.

${ }^{11}$ Milevsky and Young (2003) and Koijen, Nijman, and Werker (2006) use a constant AIR of 4 percent; this conforms to Brown et al. (2001) who note that observed AIRs fall between 3 and 4 percent. Bodie and Pesando (1983) use an AIR equal to the expected return of the annuity fund while Milevsky (2002) provides results for variable payout annuities with AIRs ranging from 2 to 8 percent.
} 
for payments, while the downside risk is limited. ${ }^{12}$

\section{The Investor's Optimization Problem}

Having introduced terminology, we now turn to a description of the retiree’s dynamic portfolio choice problem when it includes stocks, bonds, and variable life annuities. We assume the investor is endowed with initial financial assets $S_{0}$, and she is also entitled to constant real lifelong pension income of $Y_{t}=Y$ (e.g. a Social Security and/or company pension). We posit that her preferences can be characterized using a constant relative risk aversion (CRRA) utility function defined over a single non-durable consumption good. The retiree's subjective survival probability that she will survive to date $t+1$, given she is alive at $t$, is denoted $p_{t}^{s}$. In this case, the retiree's preference function is then recursively defined by:

$$
V_{t}=\frac{C_{t}^{1-\rho}}{1-\rho}+\beta E_{t}\left[p_{t}^{s} V_{t+1}+\left(1-p_{t}^{s}\right) k \frac{\left(B_{t+1}\right)^{1-\rho}}{1-\rho}\right]
$$

$$
\text { with terminal utility } \quad V_{T}=\frac{C_{t}^{1-\rho}}{1-\rho}+\beta E_{T}\left[k \frac{\left(B_{T+1}\right)^{1-\rho}}{1-\rho}\right] \text {. }
$$

Here $C_{t}$ is her consumption level at time $t ; \rho$ is her coefficient of relative risk aversion and also reflects her willingness to engage in intertemporal consumption substitution; $\beta$ reflects her time preference; and $B_{t}$ represents her remaining financial wealth at death. The strength of her bequest motive is represented by the parameter $k$. In this framework, each year the retiree must decide how to allocate her current cash on hand, $W_{t}$, between consumption $C_{t}$, financial wealth $S_{t}$ (which are her direct stock and bond investments), and new purchases of variable life annuities $P R_{t}$. Hence the budget constraint at time $t$ is given by:

\footnotetext{
${ }^{12}$ As will become apparent, the $A I R$ has implications for the timing of the annuitization and the asset allocation; below we explore how changes in the $A I R$ influence results.
} 


$$
W_{t}=S_{t}+P R_{t}+C_{t} \text {. }
$$

In the next period, cash on hand is then:

$$
W_{t+1}=S_{t}\left(R_{f}+\pi_{t}^{s}\left(R_{t+1}-R_{f}\right)\right)+L_{t+1}+Y,
$$

where $\pi_{t}^{s}$ denotes the share of financial wealth $S_{t}$ invested in risky stocks, $R_{f}$ denotes the real bond growth rate, and $R_{t+1}$ the risky stock return (assumed to be i.i.d. log-normally distributed). ${ }^{13}$ The sum of annual annuity payouts which the retiree gets from all previously purchased annuities is $L_{t+1}$. If the retiree were to die at $t+1$, the remaining estate is given by $B_{t+1}=S_{t}\left(R_{f}+\pi_{t}^{s}\left(R_{t+1}-R_{f}\right)\right)$. We note that neither the annuity nor the pension income $Y$ are available for bequests.

When the retiree purchases a variable payout life annuity in period $t=u$, her immediate single premium is defined as: $:^{14}$

$$
P R_{u}=Z_{u}^{a}(u) n_{u+1}(u) \sum_{s=u+1}^{T} \frac{65+u+s}{(1+A I R)^{u}} p^{a}
$$

In return for the premium paid at $t=u$, she receives for $t>u$ and until she dies, the annuity

payment stream represented by $Z_{t}^{a}(u) n_{t}(u)$. Thus the value of all annuity payments received at time $t+1$ from all annuities purchased previously $u \in\{0, \ldots, t\}$ is given by:

$$
L_{t+1}=\sum_{u=0}^{t} Z_{t+1}^{a}(u) n_{t+1}(u)
$$

In order to derive the stochastic evolution of $L_{t+1}$, we note that the price of one annuity fund unit

\footnotetext{
${ }^{13}$ It would be interesting to incorporate stochastic interest rates and inflation in our analysis, as in Koijen, Nijman, and Werker (2006). However that study assured model tractability by making annuitization exogenous, while our model endogenizes the annuitization strategy. Since we believe stock market risk and longevity risk are the most important risk factors in the retiree's optimal portfolio choice, and our model already includes three state variables, to reduce the curse of dimensionality we do not build in a risky term structure and/or inflation.

${ }^{14}$ Loads and administration fees for variable payout annuities in the US can vary widely and may be rather low. For example, Vanguard's website notes annual administration costs of about 0.5 percent with no commission or front loads for their variable payout annuities. We omit modeling explicit administration costs without loss of generality.
} 
of the annuity purchased at time $u$ evolves as:

$$
Z_{t+1}^{a}(u)=Z_{t}^{a}(u)\left(R_{f}+\pi_{t}^{a}\left(R_{t+1}-R_{f}\right)\right) \text {, with } Z_{u}^{a}(u)=1 \text {, }
$$

where $\pi_{t}^{a}$ is the stock fraction at time $t$ inside the variable annuities. Thus, in effect, the individual invests directly in two financial assets, riskless bonds and risky stocks, as well as indirectly through the annuity wrapper. By substituting (9) and (11) into (10), one may verify that the recursive evolution of $L_{t+1}$ is given by:

$$
L_{t+1}=\left[\frac{L_{t}}{(1+A I R)}+P R_{t}\left(\sum_{s=t+1}^{T} \frac{65+t+s}{(1+A I R)^{t-1}}\right)^{a}\right]\left(R_{f}+\pi_{t}^{a}\left(R_{t+1}-R_{f}\right)\right) .
$$

Finally, the recursive intertemporal budget restriction can then be derived by substituting equations (7) and (12) into (8):

$$
\begin{aligned}
W_{t+1} & =\left\{\left(W_{t}-C_{t}-P R_{t}\right)+\left[\frac{L_{t}}{(1+A I R)}+P R_{t}\left(\sum_{s=t+1}^{T} \frac{65+t+s}{(1+A I R)^{t}} p^{a}\right)^{-1}\right] R_{f}\right. \\
& +\left\{\left(W_{t}-C_{t}-P R_{t}\right) \pi_{t}^{s}+\left[\frac{L_{t}}{(1+A I R)}+P R_{t}\left(\sum_{s=t+1}^{T} \frac{65+t+s}{(1+A I R)^{a}}\right)^{t-1}\right] \pi_{t}^{a}\right\}\left(R_{t+1}-R_{f}\right)+Y .
\end{aligned}
$$

Besides the intertemporal budget restriction, the retiree is restricted from borrowing against future pension income and annuity payouts, as well as from selling short positions in annuities:

$$
S_{t}, P R_{t}, \pi_{t}^{a},\left(1-\pi_{t}^{a}\right), \pi_{t}^{s},\left(1-\pi_{t}^{s}\right) \geq 0
$$

Her optimization problem is then summarized by:

$$
\max _{\left\{C_{t}, P R_{t}, \pi_{t}^{s}, \pi_{t}^{a}\right\}_{t=0}^{T}} V_{0}
$$

subject to restrictions (13) and (14).

Numerical Solution. Analytical solutions to this type of problem do not exist, so we solve it by backward induction through a three-dimensional state space $\{W, L, t\}$. Although we assume 
CRRA preferences, cash on hand $W$ cannot be omitted as a state variable because illiquid annuities are included in the analysis. It is also necessary to include the sum of current annuity payouts $L$ as a state variable, because once purchased, annuities can no longer be sold. Finally, the optimal policy depends on the retiree’s age, because the price of newly purchased life annuities as well as the present value of her remaining pension income - which below we refer to as pension wealth - vary with her age.

Without loss of generality, we normalize the retiree's pension benefit $Y$ to 1 , and then we express all other cash flow variables as multiples of $Y$. There are three state variables, two of which - cash on hand $W$ and annuity payouts $L$ - are continuous, leaving age as the only discrete state variable. For each grid point, we calculate the optimal policy and the value of the value function. Thereby, we compute the integral of the expectation operator in (6):

$$
E_{t}\left[p_{t}^{s} V_{t+1}+\left(1-p_{t}^{s}\right) k \frac{\left(B_{t+1}\right)^{1-\rho}}{1-\rho}\right]=\int\left[p_{t}^{s} V_{t+1}+\left(1-p_{t}^{s}\right) k \frac{\left(B_{t+1}\right)^{1-\rho}}{1-\rho}\right] p\left(R_{t+1}\right) d R_{t+1}
$$

using Gaussian quadrature integration. The optimization is done by numerical constrained maximization. We estimate the policy functions $C(W, L, t), P R(W, L, t), \pi^{s}(W, L, t), \pi^{a}(W, L, t)$ and the value function $V(W, L, t)$ by cubic spline interpolation.

\section{Optimal Policies for a Range of Base Cases}

To illustrate the range of asset location and allocation strategies, we graph the optimal positions for hypothetical retirees of different ages and different initial financial wealth values (represented as a multiple of pension income). In Figure 2, for instance, the retiree has moderate relative risk aversion ( $\rho=5$ ), a reasonable rate of time preference ( $\beta=0.96$ ), no bequest 
motive $(k=0)$, and no income from preexisting annuities $(L=0) .{ }^{15}$ Panels $(a)$ and $(b)$ show that all consumers will partially annuitize immediately, but even without a bequest motive, most will keep up to 13 percent of their initial assets in financial wealth. Also, most retirees will postpone full annuitization until later in life, until around age 88. The reason for partial annuitization is that our analysis permits retirees to purchase only annuities with lifelong payouts. ${ }^{16}$

Accordingly, as we demonstrate below, full initial annuitization as imposed in earlier studies is suboptimal when assuming reasonable parameters. ${ }^{17}$

Figure 2 here

The reason that the consumer holds on to her non-annuitized wealth early in retirement is that annuity payouts are low initially and rise later in life, because the expected annuity return exceeds the $A I R$. Due to her time preference, the retiree who seeks to smooth consumption will keep some liquid financial wealth from which she can withdraw cash flexibly to compensate for the low initial annuity payments. Of course, while keeping some financial wealth is optimal, it is also worth noting that the mortality credit in the annuity largely compensates for the rigidity of the annuity payout pattern. ${ }^{18}$

Figure 2 also reveals that the retiree initially holds a substantial fraction of her annuity in stocks, and in some cases as much as 100 percent (Panels $c$ - $d$ ). In most cases, the share of her

\footnotetext{
${ }^{15}$ Survival probabilities are taken from the US 1996 Annuity 2000 female mortality table to price annuities, and from the corresponding population mortality table to calculate utility. To reduce computation times, we restrict the maximum age to 100 . The riskless rate is set to 2 percent and the $A I R$ to 4 percent, respectively. Further, we assume that risky stock has an expected return of 6 percent and volatility of 18 percent.

${ }^{16}$ This assumption creates market incompleteness as annuities that pay out only in one specific year, as in Davidoff et al. (2005) and Kapur and Orszag (1999), are not available Our approach to modeling annuity markets is more consistent with real world annuity products.

${ }^{17}$ For example, studies by Browne, Milevsky, and Salisbury (2003); Charupat and Milevsky (2002); and Koijen, Nijman, and Werker (2006) assume incomplete annuity markets but exogenously impose immediate full annuitization at the point of retirement .

${ }^{18}$ Milevsky and Young (2006a) derive the optimal timing to switch to what they call an optimal money mix plan. This is a full annuitization strategy where at retirement, the consumer selects a given fraction of fixed and equitylinked payout annuities. Postponing annuitization is optimal in this setting because the retiree is restricted to full annuitization and cannot later rebalance the fraction of fixed and equity-linked payout annuities.
} 
financial wealth in stocks is also high early in retirement, and then falls for older retirees. The optimal stock fraction in the variable annuity declines at older ages, as well as in the financial portfolio. The reason is that the retiree's pension wealth has bond-like traits, and it declines (in present value) over time. Accordingly, the retiree phases down her stock allocation (taking into account both financial and variable annuity assets), so as to maintain a total stock fraction when a bond-like pension wealth shrinks over age. Also, the higher her financial wealth compared to pension wealth, the higher is her desired bond exposure as a percent of her financial wealth if she is to reach her optimum investment mix. This result is similar to those suggested by recent lifecycle asset allocation studies which omit annuities (Cocco, Gomes, and Maenhout, 2005), and it also conforms to financial advice recommending that stock fractions be decreased for older individuals (Young, 2004).

Figure 3 provides illustrative optimal stock fractions in the combined annuity and financial wealth portfolios, depicted as a function of the retiree's age and cash on hand $(W)$. Panel $(a)$ confirms that the retiree's overall fraction in stock declines with age. In Panel (b), the optimal stock fraction varies according to the retiree's initial wealth, and once again it falls with age, more rapidly for higher levels of initial wealth. It is interesting that this pattern implies the retiree will follow a counter-cyclical investment strategy, boosting her stock fraction after a bear market and decreasing it in a bull market. ${ }^{19}$ This stands in sharp contrast with conventional buyand-hold pro-cyclical "money mix" strategies, ${ }^{20}$ since in the latter, the stock fraction rises when the stock market outperforms the bond market, and falls if the stock market dives.

Figure 3 here

\footnotetext{
${ }^{19}$ In many countries, insurance contracts include a guarantee which leads to a procyclical investment policy on behalf of the insured person; we find the opposite to be optimal for the CRRA investor.

${ }^{20}$ See Charupat and Milevsky (2002), Koijen, Nijman, and Werker (2006), Browne et al. (2003), and Milevsky and Young (2003).
} 
Stochastic Analysis. Next we undertake stochastic analysis to evaluate how the retiree's annuity purchases, stock fraction, and consumption, would be expected to evolve assuming she followed the policy functions derived above. These computations are based on Monte Carlo simulations of 100,000 life cycles, and they all begin by assuming that her financial wealth at age 65 amounts to 5 times her pension income; accordingly, total cash on hand (including pension income) is 6 times pension income $(W=6)$. Further, we assume that she holds no initial variable payout annuities $(L=0)$.

The range of simulated possibilities appears in Figure 4, taking into account the consumer's optimal portfolio rebalancing. The median path $\left(50^{\text {th }}\right.$ percentile $)$ in Panel $(a)$ indicates that the retiree will purchase the bulk of her annuities at age 65 and continue to add additional units thereafter; accordingly, her annuity wealth rises with age and after age 80 she is fully annuitized. Yet because outcomes are stochastic, the $10-90^{\text {th }}$ percentiles illustrate likely variability. In Panel (b), we see that the retiree permitted to rebalance her variable payout annuity asset allocation as she ages will reduce her stock fraction along the median path. In addition, the dispersion in the fraction of stock held rises over time, ranging between 50 and 100 percent.

Figure 4 here

Panel (c) of Figure 4 traces the dispersion of consumption paths with age, where consumption is measured as a multiple of pension income. At the median, the optimizing retiree boosts consumption by 40 percent over her pension income for the rest of her life. The payouts could be substantially higher, doubling her consumption, if the stock market behaves extremely well when she is in her 90s; conversely the annuity would only boost consumption by 10-20 percent, if the assets in the variable annuity perform very poorly (represented in the figure by the 10 percentile probable minimum consumption level). In other words, with variable payout 
annuities, the retiree may deplete her financial assets not because of longevity risk, but because of stock market risk.

Impact of the AIR. Above we noted that the AIR selected by the insurer may have a considerable influence on the annuity payout pattern, as well as the retiree's asset location and allocation decisions. This because the retiree who buys an annuity is restricted to receiving a certain payout pattern determined by the $A I R$. When the $A I R$ is low, annuity cash flows are initially low but rise later in life; conversely, a high AIR produces higher initial cash flows which can be optimally reinvested according to the realized state of nature, but this comes at the cost of lower benefits late in life. It is therefore of interest to explore how changing the AIR shapes the investor's optimal asset allocation, and to determine how sensitive the optimal outcomes are to changes in the $A I R$.

To this end, we reoptimize the retiree’s asset allocation policy for AIRs set to 2, 4, and 6 percent and compare the Monte Carlo simulations based on the optimal policies resulting in each case. Figure 5 reports results, with Panel (a) providing expected financial wealth holdings. When the $A I R$ is low, the retiree retains a large financial wealth position early in retirement; for instance, given an AIR of 2 percent, she holds 25 percent of her total wealth in nonannuitized form. As the $A I R$ rises, the portion held in annuities also increases; thus if the $A I R$ is 6 percent, all wealth will be immediately annuitized at age 65 . This is because annuity payments are low when the $A I R$ is low, and to smooth consumption, the retiree will retain more financial wealth. Conversely, for higher $A I R s$, the annuity benefits will be high, and she can invest a portion of the benefit in newly purchased annuities, if she does not need the income.

Figure 5 here

Raising the $A I R$ also produces a twist in the term structure of the retiree's stock holdings as 
a fraction of combined financial and annuity wealth (Panel $b$ ). At retirement, she holds all of her assets in stock, independently of the AIR; thereafter, the expected stock fraction falls with age. Furthermore, if the $A I R$ is low, this decline in the stock fraction is slightly smaller early in retirement, compared to higher AIRs. After the retiree reaches her mid-70's, the rate of decline is greater for a lower $A I R$. This is because a low $A I R$ requires the retiree to reduce her stock fraction more over time as the payout volatility rises faster than with a high AIR (see Figure 1). Finally, a higher $A I R$ also gives the retiree a smoother consumption profile (Panel $c$ ), as she need not miss out on the mortality credit by maintaining high levels of liquid financial wealth early in her retirement period.

\section{Utility Gains from Variable Payout Annuities}

Thus far, we have shown that the retiree will optimally devote a dominant portion of her portfolio to variable payout annuities, and she also will hold substantial equities. To evaluate how consequential variable payout annuities are for the retiree's wellbeing, we next compare the retiree’s utility from having access to variable annuities, with those achievable from a phased withdrawal strategy. We compare these alternatives by computing the additional amount of financial wealth the retiree would need in the restricted scenario, that would make her as well off (provide the same expected utility) as in the unrestricted scenario. Technically, this is accomplished by equating the expected utility in the unrestricted case with that of the restricted case but with more initial financial wealth.

In particular, we examine two phased withdrawal strategies, namely (1) a Pure Bond Strategy with no Annuities, and (2) a Stock/Bond Strategy with no Annuities. The first assumes that the investor follows a dynamic optimal phased withdrawal plan, but she can hold no 
annuities and may invest only in bonds. This calculation offers insight into welfare gains associated with access to both the equity premium offered by the stock market and the mortality credit offered by the annuity market. In the second case, the investor is assumed to optimally invest her assets in stocks and bonds, but she cannot buy annuities. This second scenario isolates the utility value of access to annuity markets alone.

The left-hand panel of Table 1 summarizes results for a moderately risk-averse individual such as that depicted in Figure 2, for varying initial wealth levels. We also allow a bequest motive in the last panel. It is unequivocally clear that annuities enhance retiree wellbeing irrespective of risk aversion. Previously, we had showed that the moderately risk averse retiree with moderate initial wealth $\left(\rho=5\right.$ and $\left.\mathrm{S}_{0}=5\right)$ will initially invest all her financial and annuity funds in stocks. By contrast, Column 2 indicates what happens if that retiree were constrained to a phased withdrawal strategy and could invest only in bonds. Specifically, row 3 shows that she would need to be given 34 percent more initial financial wealth to make her indifferent between the pure bond phased withdrawal approach, versus having an unconstrained menu. This utility change is substantial, and it is comparable to values reported by Brown et al. (2001) where their benchmark involved only immediate and full annuitization. Values for other levels of risk aversion are similar (rows 1 and 5).

\section{Table 1 here}

A retiree who lacks a variable annuity but has access to both stock and bond markets is relatively better off. Column 2 , row 4 , for instance, shows that our moderately risk-averse retiree still allocates her funds suboptimally, but since she can now benefit from the equity premium, she requires only 13 percent of her initial financial wealth to be as well off as she would with access to a variable annuity. In fact, the difference between rows 3 and 4 measures the value of 
equity premium which, in this case, exceeds 20 percent of initial wealth. More generally, the higher are initial wealth and risk aversion levels, the more the retiree will value access to the variable annuity market. For example, the very risk-averse retiree $(\rho=10)$ with a high level of initial financial wealth $\left(S_{0}=10\right)$ who can only invest in bonds, would require a 41 percent increase in her initial wealth to make her as well off as with the full range of portfolio choices. Of course, if there is a positive bequest motive, the relative appeal of annuities is lower. But even here, the value of access to variable annuity markets still rises with initial wealth.

The right-hand panel of Table 1 provides results for alternative AIRs at varying levels of risk aversion, assuming the initial financial wealth is fixed $\left(\mathrm{S}_{0}=5\right)$. The overall conclusion is that higher AIRs are appealing to more risk averse individuals having access to variable annuities. By contrast, a lower AIR is preferred by the more risk tolerant. The case with bequests (rows 7 and 8 ) is comparable to the no-bequest scenario: the retiree will select a high AIR. In any event, changes in utility are small which suggests that offering retirees choice over AIRs (within reason) is unlikely to be consequential. ${ }^{21}$

The welfare gains from this complex process of dynamic portfolio reoptimization can be compared to simpler one-time annuitization and portfolio investment decisions such as the constant 60/40 stock/bond mix mentioned by Feldstein and Ranguelova (2001). It is interesting that relatively small levels of incremental financial wealth would leave the retiree indifferent between our optimally dynamic retirement strategy and a simple, fixed 60/40 investment mix. For retirees with the risk aversion and initial financial wealth levels considered above, the simpler rule produces utility losses equivalent to no more than 8 percent of initial financial

\footnotetext{
${ }^{21}$ Dellinger (2006) notes that some variable payout annuities providers let the annuitant select an AIR from a certain range at the time the annuity is purchased. But as suggested by Jeffrey Brown (personal communication), permitting annuity purchasers to freely choose their preferred AIR may foster adverse selection: thus retirees believing they have inside information about their own mortality prospects might select their AIR strategically. It would be interesting to examine this hypothesis empirically.
} 
wealth. Nevertheless, other simple rules (such as holding 100 percent of the annuity in stock) are much less attractive.

\section{Discussion and Conclusions}

Those working to manage their money effectively in retirement seek to benefit from capital market returns while not outliving their funds. This paper shows how variable payout annuities can enhance the retiree portfolio choice set taking into account both stochastic mortality and risky stock returns, particularly if variable annuities can be bought endogenously. Our work advances prior studies by allowing the investor to annuitize gradually; endogenizing the annuitization decision means she holds annuities and financial wealth simultaneously and can buy annuities incrementally in retirement. We also endogenize the asset allocation decision both inside and outside the variable payout annuities. And finally, we assess how pre-retirement saving, income, and bequest motives affect the analysis.

Regarding the asset location decision, we find that the utility maximizing retiree will not annuitize all her funds at retirement, even if she has no bequest motive. This result contrasts with prior studies which suggest that retirees lacking a bequest motive will annuitize all their wealth. For example, a moderately risk averse and moderately endowed investor will hold up to one-quarter of her initial wealth in financial assets at retirement; thereafter, she will draw from this fund over time to smooth her consumption time path. Full annuitization is deferred to around age 80 at the latest. Regarding her asset allocation decision, it is interesting that the retiree will optimally invest a majority of her combined annuity and financial wealth in stock, with the stock fraction falling over the retirement period. We also show that the investor will react countercyclically with respect to stock market trends, so as to rebalance her asset allocation. By 
contrast, prior studies advocating a buy-and-hold approach to annuities tell retirees to follow a procyclical investment strategy. Changes in the $A I R$ (within a reasonable range) have a relatively small impact. Last, our welfare analysis indicates that a retiree who can access variable annuities or stocks values this considerably, for a wealth equivalent amounting to as much as 40 percent of initial financial wealth.

Our findings are consequential for retirees as well as insurers and financial planners, since we have identified a substantial degree of improvement in consumer wellbeing resulting from access to variable annuities and equities in the retirement portfolio. Policymakers and designers of defined contribution pensions and Individual Retirement Accounts can incorporate variable payout annuities in the retirement mix as an appealing compromise between the extremes of a pure withdrawal plan, on the one hand, and a fixed annuity, on the other. It is worth noting that the US Congress recently recommended that life cycle funds become the default for pension participant's accumulation phase, but it offered no guidance on how the funds should be managed after retirement (Purcell 2006). Likewise, the President’s Commission to Strengthen Social Security focused on ways to help workers accumulate assets, but it remained silent regarding ways to help retirees manage the asset decumulation process (Cogan and Mitchell, 2003). Our analysis implies that integrated methods to finance retirement offer enormous potential for both investment managers and insurance companies to capture the \$15 trillion of Baby Boomer money in motion. 


\section{References}

Blake D., A. Cairns and K. Dowd, 2003, Pensionmetrics 2: Stochastic Pension Plan Design during the Distribution Phase, Insurance: Mathematics and Economics, Vol. 33, Issue 1, p.29-47.

Bodie, Z., and J. Pesando, 1983, Retirement Annuity Design in an Inflationary Climate, in Z. Bodie and J. Shoven, eds., Financial Aspects of the U.S. Pension System, University of Chicago Press: Chicago, IL.

Brown, J.R., O.S. Mitchell, and J.M. Poterba, 2001, The Role of Real Annuities and Indexed Bonds in an Individual Accounts Retirement Program, in J.Y. Campbell and M. Feldstein, eds., Risk Aspects of Investment-Based Social Security Reform, University of Chicago Press: Chicago, IL, p.321360.

Browne, S., M.A. Milevsky, T.S. Salisbury, 2003, Asset Allocation and the Liquidity Premium for Illiquid Annuities, Journal of Risk \& Insurance,Vol. 70, Issue 3, p.509-526.

Charupat, N., and M.A. Milevsky, 2002, Optimal asset allocation in life annuities: a note, Insurance: Mathematics and Economics, Vol. 30, Issue 2, p.199-209.

Cocco, J.F., F.J. Gomes, and P.J. Maenhout, 2005, Consumption and Portfolio Choice over the Life Cycle, Review of Financial Studies, 18, p.491-533.

Cogan, J.and O. S. Mitchell. 2003. "Perspectives from the President's Commission on Social Security Reform.” Journal of Economic Perspectives. 17(2). Spring.

Davidoff T., J. Brown and P. Diamond, 2005, Annuities and Individual Welfare, American Economic Review, 95 (5), p.1573-1590.

Dellinger, J.K., 2006, The Handbook of Variable Income Annuities, John Wiley \& Sons, Inc., Hoboken, New Jersey, USA.

Dus, I., R. Maurer, and O.S. Mitchell, 2005, Betting on Death and Capital Markets in Retirement: A Shortfall Risk Analysis of Life Annuities versus Phased Withdrawal Plans, Financial Services Review 14, 2005, p.169-196.

Feldstein, M. and E. Ranguelova. 2001. Individual Risk in an Investment-Based Social Security System. American Economic Review 91(4): 1116-1125.

Gerrard, R., S. Haberman, and E. Vigna, 2004, Optimal Investment Choices Post-retirement in a Defined Contribution Pension Scheme, Insurance: Mathematics and Economics, Volume 35, Issue 2, p.321-342.

Horneff, W.J., R. Maurer, O.S. Mitchell, and I. Dus, 2006, Optimizing the Retirement Portfolio: Asset Allocation, Annuitization, and Risk Aversion, NBER Working Paper 12392.

Horneff, W.J., R. Maurer, and M. Stamos, 2006a, Life-Cycle Asset Allocation with Annuity Markets: Is Longevity Insurance a Good Deal?, Working Paper, Goethe University, Frankfurt.

Horneff, W.J., R. Maurer, and M. Stamos, 2006b, Optimal Gradual Annuitization: Quantifying the Costs of Switching to Annuities, Working Paper, Goethe University, Frankfurt.

Kaplan, P.D., 2006, Asset Allocation with Annuities for Retirement Income Management, Journal of Wealth Managament, Vol. 8, No. 4, (Spring 2006), p.27-40.

Kapur, S. and J. Orszag, 1999, A Portfolio Approach to Investments and Annuitization During Retirement, Working Paper, Birbeck College, University of London, UK. 
Kingston, G. and S. Thorp, 2005, Annuitization and Asset Allocation with HARA Utility, Journal of Pension Economics and Finance, 4, p.225-248.

Koijen, R.S., T. Nijman, and B.J.M. Werker, 2006, Optimal Portfolio Choice with Annuitization, Working Paper, Tilburg University - Center for Economic Research.

McKinsey, 2006, Cracking the Consumer Retirement Code. McKinsey \& Co.

Milevsky, M.A., 1998, Optimal asset allocation towards the end of the life cycle: To annuitize or not to annuitize?, Journal of Risk \& Insurance, Vol. 65, Issue 3, p.401-426.

Milevsky, M.A., 2002, How to Completely Avoid Outliving Your Money: An Introduction to Variable Payout Annuities for Retiring Canadians, Working Paper, IFID Centre, The Schulich School of Business, York University, Toronto, Canada.

Milevsky, M.A. and V. Young, 2002, Optimal Asset Allocation and the Real Option to Delay Annuitization, Working Paper, IFID Centre, Schulich School of Business, York University, Toronto, Canada.

Milevsky, M.A. and V. Young, 2006a, Annuitization and Asset Allocation, in Journal of Economic Dynamics and Control forthcoming.

Milevsky, M.A. and V. Young, 2006b, The Timing of Annuitization: Investment Dominance and Mortality Risk, Insurance: Mathematics and Economics, forthcoming.

Milevsky, M.A., K.S. Moore, and V. Young, Asset Allocation and Annuity-Purchases Strategies to Minimize the Probability of Financial Ruin, Mathematical Finance, 16, (4), 647-671.

Mitchell, O., J. Poterba, M. Warshawsky, and J. Brown, 1999, New Evidence on the Money’s Worth of Individual Annuities, American Economic Review, 89, p.1299-1318.

Purcell, Patrick, 2006, Summary of the Pension Protection Act of 2006. Congressional Research Service, Domestic Social Policy Division. Working Paper. US Congress.

Stabile G., 2003, Optimal Timing of the Annuity Purchases: A Combined Stochastic Control and Optimal Stopping Problem, Working Paper, Universita degli Studi ”La Sapienza” di Roma, Rome, Italy.

Yaari M., 1965, Uncertain Lifetime, Life Insurance, and the Theory of the Consumer, Review of Economic Studies, 32, p.137-150.

Young, L., 2004, “Funds That Adjust As The Years Go By.” Business Week, July 26. 
Panel (a)

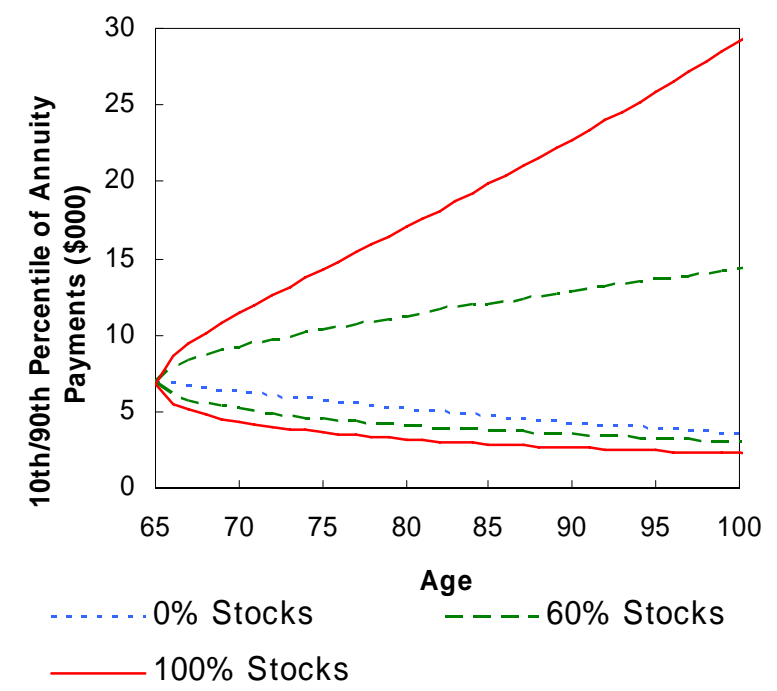

Panel (b)

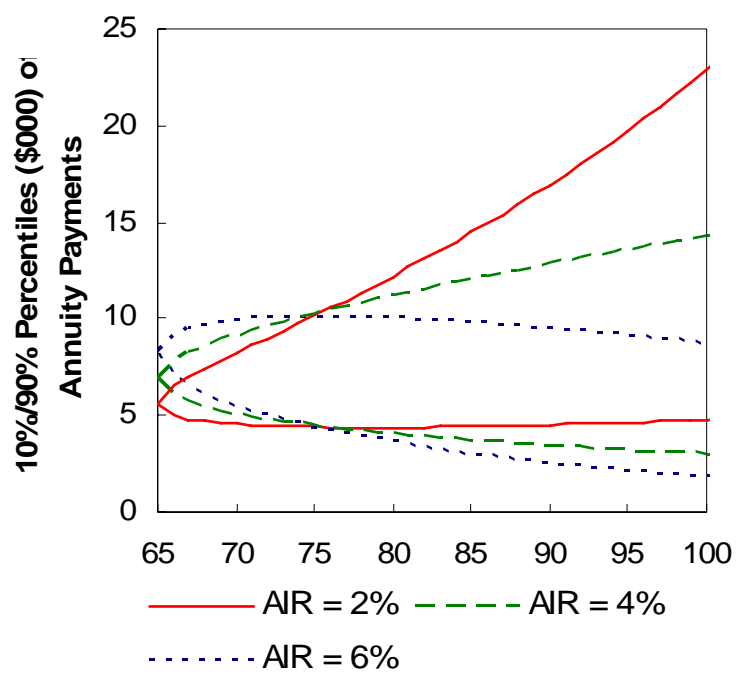

Figure 1: Payment Percentiles for Alternative Asset Allocations in the Annuity and Varying

AIRs.

This illustration assumes an initial premium of $\$ 100,000$ and survival probabilities from the US 1996 Annuity 2000 mortality table for females; computations are based on equation (5). Panel a: Yearly real annuity fund returns for the 60 (100) percent stock allocation are i.i.d. log-normal with mean 4.4 (6) percent and standard deviation 10.8 (18) percent. The real riskless rate and the $A I R$ are set to 2 and 4 percent, respectively. Panel $b$ : The annuity fund is assumed to be invested in a 60/40 stock bond portfolio with the mean 4.4 percent and standard deviation 10.8 percent; the $A I R$ is set to 2, 4, and 6 percent, respectively. 


\section{Annuity Wealth}

(a)

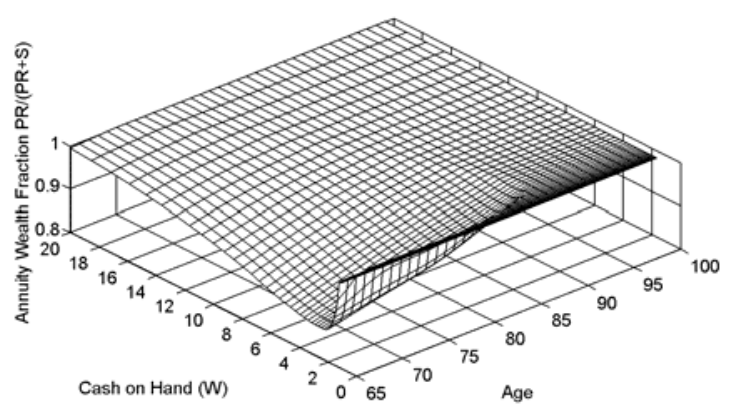

(c)

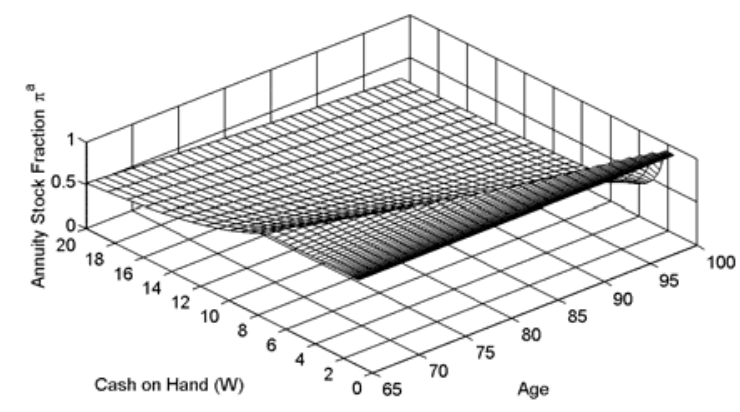

Financial Wealth

(b)

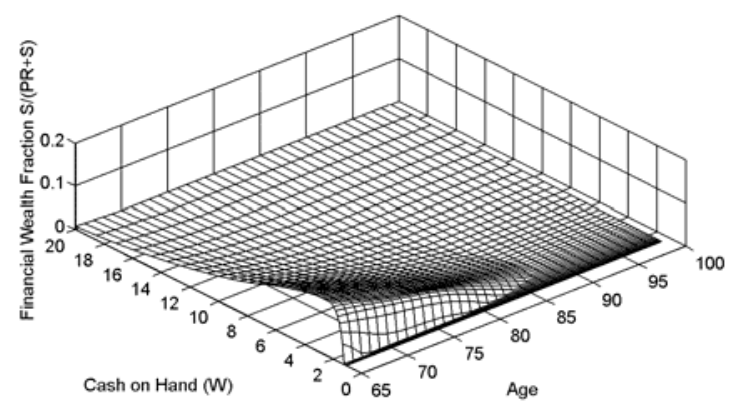

(d)

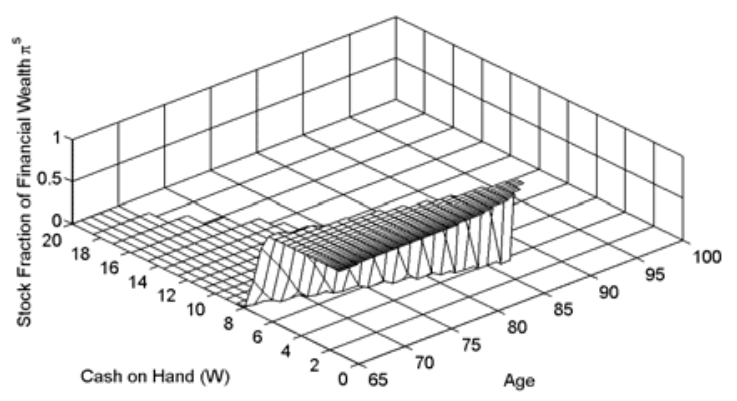

Figure 2: Illustrative Optimal Dynamic Asset Location and Allocation given Stocks, Bonds, and Variable Payout Annuities: Variations by Age and Cash on Hand. These figures represent optimal policies which vary as a function of cash on hand $(W)$ and age; in all panels, no prior annuitization is assumed $(L=0)$. In Panel $(a)$, the age-65 retiree with cash on hand $W=6$ would spend 90 percent of her cash on annuities and the rest to financial investments (Panel $b$ ). Her optimal stock fraction is 100 percent within the variable annuity (Panel $c$ ) as well as in financial wealth (Panel $d$ ).

Note: Calculations are based on backward optimization of the value function given in (15). The retiree has $C R R A$ utility with $\rho=5, \beta=0.96$, and no bequest motive $(k=0)$. Survival probabilities are from the US 1996 Annuity 2000 mortality table for females to price annuities and from the corresponding population mortality table to calculate utility. Yearly real stock returns are i.i.d. log-normal distributed with the mean 6 percent and standard deviation 18 percent. The real interest rate and the AIR are set to 2 and 4 percent, respectively. 
(a) How Optimal Stock Holdings as a Fraction of Combined Annuity and Financial Wealth Portfolios Vary by Age and Cash on Hand: No Prior Annuity Assumed (i.e. $L=0$ )

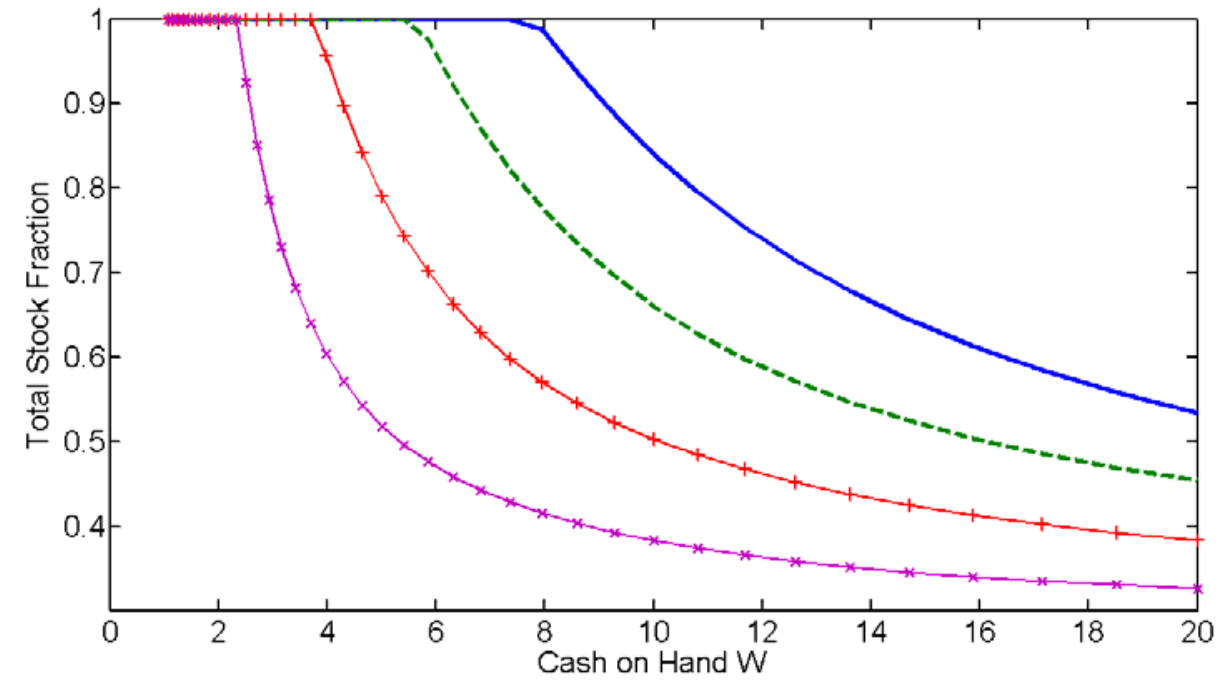

(b) How Optimal Stock Holdings as a Fraction of Combined Annuity and Financial Wealth Portfolios Vary by Age and Initial Wealth: Single Level of Cash on Hand Assumed $(W=6)$

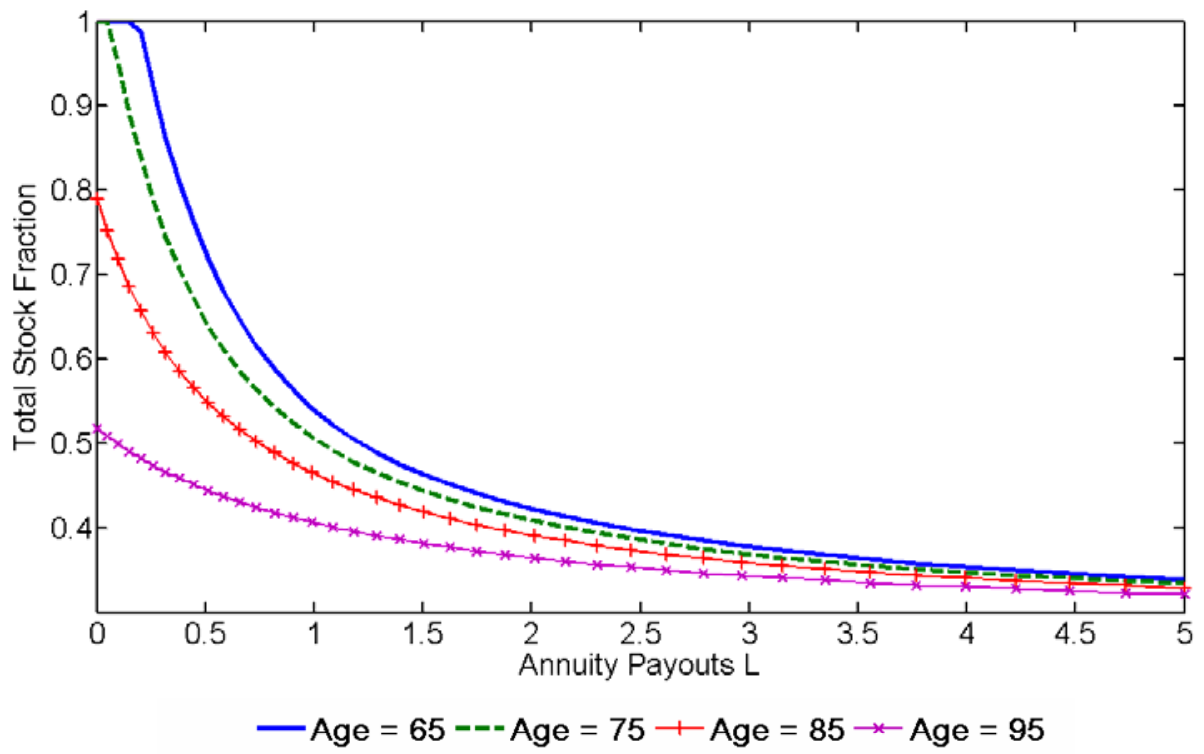

Figure 3: Illustrative Optimal Stock Fractions in the Combined Annuity and Financial Wealth Portfolios. These figures represent the relationship between the retiree's age and the optimal stock fraction in her combined annuity and financial asset holdings. The latter is defined as the stock fraction of her expected annuity wealth $P V$ (the present value of remaining expected annuity payouts ) plus the stock fraction of her financial wealth $S$, as a percent of financial plus annuity wealth $\left(\pi^{s} S+\pi^{a} P V\right) /(S+P V)$. Panel (a) shows how this stock fraction varies with age and cash on hand $W$; Panel (b) shows how it varies with age and pre-existing annuity payments $L$. In both panels, no prior annuitization is assumed $(L=0)$. Note: See Figure 2 for calculation details. 
(a)

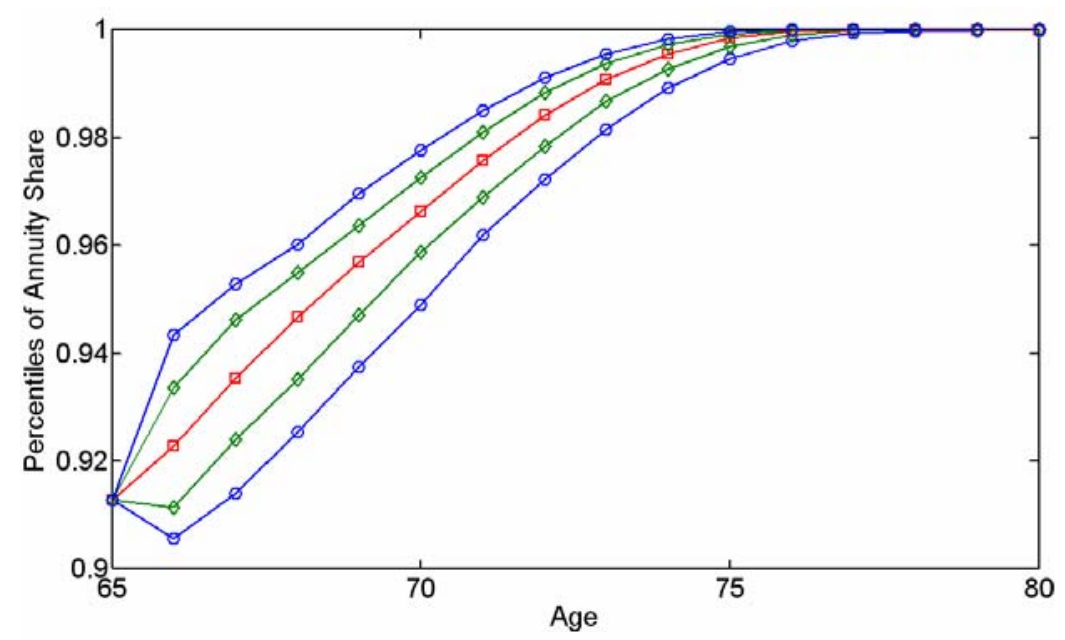

(b)

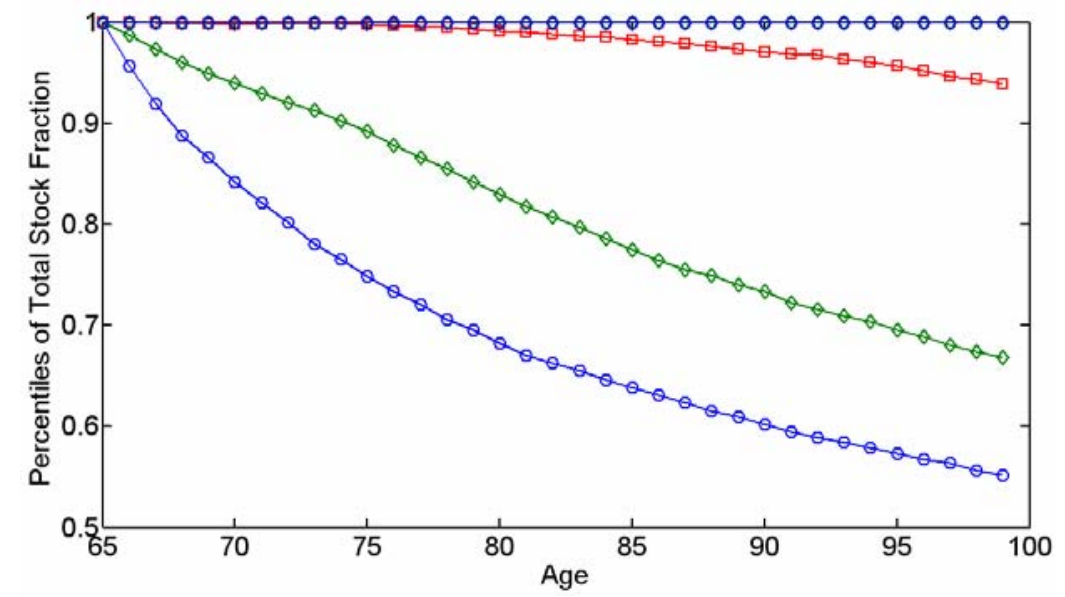

(c)

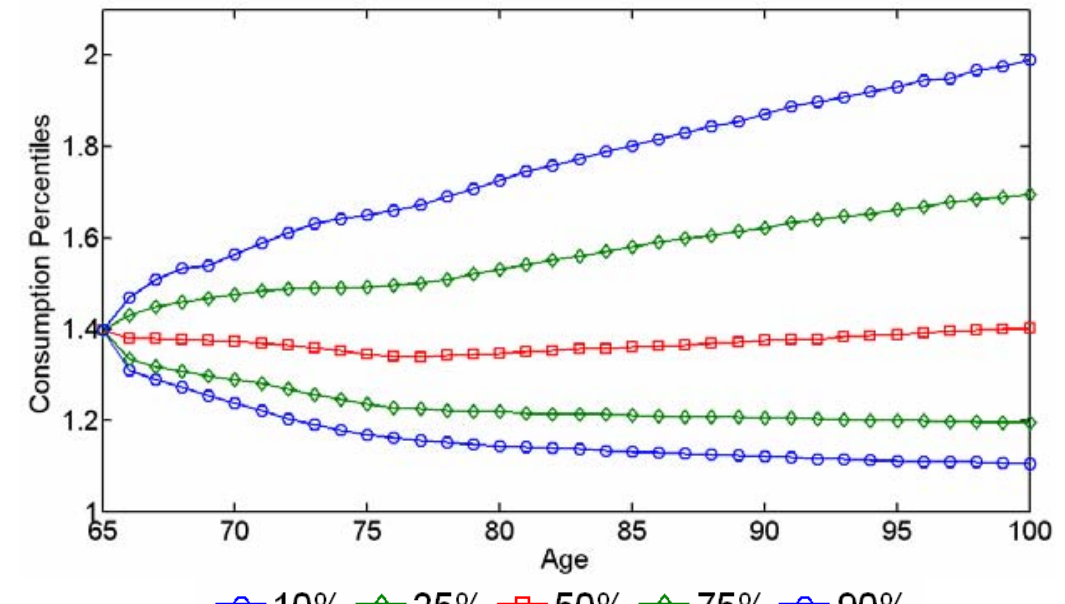

Figure 4: Dispersion of Annuity, Total Stock, and Consumption Paths: Base Case. Panel (a) depicts the dispersion of the annuitized fraction of wealth $P V /(S+P V)$ as it varies with age; Panel (b) reports similar age-dispersion percentiles for the stock fraction of the combined annuity and financial wealth portfolios $\left[=\left(\pi^{s} S+\pi^{a} P V\right) /(S+P V)\right]$. Panel (c) shows similar dispersion for consumption, measured as a multiple of pension income.

Note: See Figure 2 for details. Computations are based on 100,000 Monte Carlo simulations using the optimal policies from Figure 3 and initial wealth of 5 times pension income $\left(S_{0}=5\right)$. 


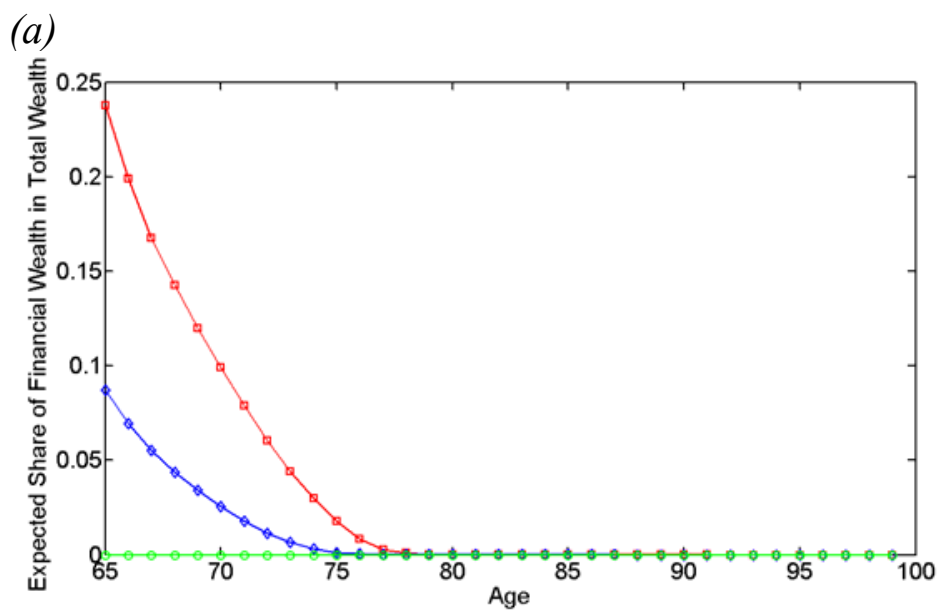

(b)

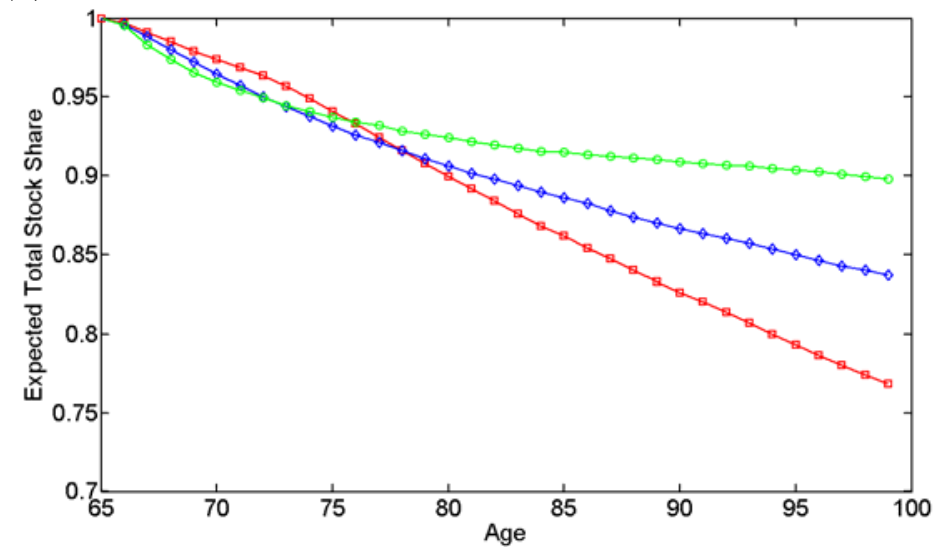

(c)

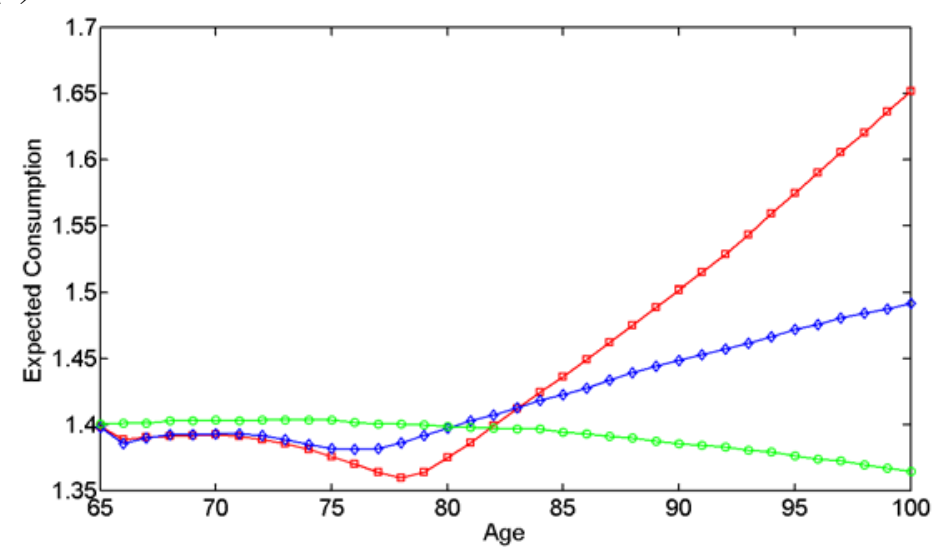

$\rightarrow-\mathrm{AIR}=2 \% \rightarrow \mathrm{AIR}=4 \% \rightarrow-\mathrm{AIR}=6 \%$

Figure 5: Impact of Changing the AIR on $(a)$ the Expected Share of Financial Wealth, $(b)$ Total Stock Share, and $(c)$ Consumption. This figure depicts the results from solving the optimization problem in (15) for AIRs of 2, 4, and 6 percent respectively. Note: See Figure 4 for details. 
Table 1: Required Increase in Financial Wealth (\%) to Make Retiree Indifferent Between the Specified Phased Withdrawal Strategy versus Gaining Access to Variable Payout Annuities: Impact of Different Preferences, Initial Financial Wealth, and AIR.

\begin{tabular}{|c|c|c|c|c|c|c|c|c|}
\hline & \multirow[b]{3}{*}{ Preferences } & \multirow[b]{3}{*}{ Investible Assets } & \multicolumn{3}{|c|}{ Initial Financial Wealth } & \multicolumn{3}{|c|}{ AIR } \\
\hline & & & $\begin{array}{c}\text { Low } \\
\left(S_{0}=2\right)\end{array}$ & $\begin{array}{c}\text { Moderate } \\
\left(S_{0}=5\right)\end{array}$ & $\begin{array}{c}\text { High } \\
\left(S_{0}=10\right)\end{array}$ & $\begin{array}{c}\text { Low } \\
(A I R=2 \%)\end{array}$ & $\begin{array}{c}\text { Moderate } \\
(A I R=4 \%)\end{array}$ & $\begin{array}{c}\text { High } \\
(A I R=6 \%)\end{array}$ \\
\hline & & & (1) & (2) & (3) & (4) & $(5)$ & (6) \\
\hline \multirow[t]{2}{*}{ (a) } & Low Risk Aversion & (1) Bonds & 19.8 & 30.5 & 36.8 & 38.1 & 30.5 & 31.4 \\
\hline & $(\rho=2, k=0)$ & (2) Bonds, Stocks & 6.3 & 9.6 & 12.5 & 15.7 & 9.6 & 10.3 \\
\hline \multirow[t]{2}{*}{ (b) } & Moderate Risk Aversion & (3) Bonds & 24.8 & 34.0 & 37.8 & 32.6 & 34.0 & 34.9 \\
\hline & $(\rho=5, k=0)$ & (4) Bonds, Stocks & 7.9 & 13.1 & 18.3 & 11.9 & 13.1 & 13.8 \\
\hline \multirow[t]{2}{*}{ (c) } & High Risk Aversion & (5) Bonds & 29.1 & 36.1 & 40.6 & 34.6 & 36.1 & 37.7 \\
\hline & $(\rho=10, k=0)$ & (6) Bonds, Stocks & 12.1 & 19.8 & 27.6 & 18.5 & 19.8 & 20.4 \\
\hline \multirow[t]{2}{*}{ (d) } & Moderate Bequest Motive & (7) Bonds & 24.3 & 27.8 & 31.2 & 27.7 & 27.8 & 28.2 \\
\hline & $(\rho=5, \mathbf{k}=2)$ & (8) Bonds, Stocks & 4.2 & 7.0 & 12.5 & 6.8 & 7.0 & 7.7 \\
\hline
\end{tabular}

Note: The table entries indicate the amount of financial wealth the retiree would have to be given to make her indifferent between having access to variable annuities as well as stocks and bonds, versus having a restricted choice set as indicated in the Table. For example, the investor with relative risk aversion $\rho=5$, no bequest motive $(k=0)$, and an initial financial wealth of $S_{0}=5$, who can invest just in bonds, would be indifferent between having access to the variable annuity market, versus being compensated with an additional 34 percent of financial wealth (row b3, col. 2). The impact of financial wealth is evaluated fixing the $A I R$ of the variable annuity to $A I R=4 \%$. The impact of the $A I R$ is calculated fixing initial financial wealth at $S_{0}=5$. 